\title{
Body condition score at lambing and performance of Santa Inês ewes with an offspring during lactation
}

\section{Escore de condição corporal ao parto e desempenho de ovelhas Santa Inês e de seus cordeiros durante $1^{\text {a }}$ lactação}

\author{
Edson Luis de Azambuja Ribeiro ${ }^{1 *}$; Filipe Alexandre Boscaro de Castro'; Valter \\ Harry Bumbieris Junior ${ }^{1}$; Odimári Pricila Prado-Calixto ${ }^{1}$; Leandro das Dores \\ Ferreira da Silva1; Amanda de Freitas Pena²; Eliel González-García ${ }^{3}$
}

\section{Highlights}

Ewes have adapted to a negative energy balance from the periparturient period.

Ewes with BCS between 2.0 and 3.5 do not affect the performance of their lambs.

Even with a slight negative energy balance, sheep can maintain good milk production.

\begin{abstract}
The main objective of this study was to evaluate the performance of Santa Inês ewes using their body condition score (BCS) at lambing. Data from 135 adult ewes with singletons were investigated. Ewes were divided into three distinct groups: 1) Below average: BCS < 2.5 points $(n=44) ; 2)$ Average: BCS between 2.5 and 3.0 ( $n=53)$; and 3) Above average: BCS > $3.0(n=38)$. The scale for BCS varied from 1 (very thin) to 5 (very fat). The individual BW, BCS, metabolic profile, milk production, and composition of ewes as well as their lambs' performance until weaning were studied. Metabolic profile was monitored relative to lambing at $-7,+7$, and +60 days. It was observed that ewes with a higher BCS were also heavier; however, there were no differences in the lambs among the groups for weight at birth and weaning (70 days). As there was no difference in milk production and composition, the average daily weight gain of the lambs was similar regardless of the ewe's BCS. The metabolic profile (hemoglobin, total protein, albumin, creatinine, urea, glucose, $\beta$-hydroxibutyrate, cholesterol, and aspartate aminotransferase - AST) were also similar among the groups. However, when the metabolic profile was compared with the different physiological stages relative to lambing, some differences were observed. For example, $\beta$-hydroxibutyrate was greater during the peripartum period, and glucose was greater in the lactation phase. It was concluded that even in a situation

1 Profs., PhD, Department of Zootechnics, State University of Londrina, UEL, Londrina, PR, Brazil. E-mail: elar@uel.br; fabcastro76@yahoo.com.br; jrbumbieris@uel.br; odimari@gmail.com; leandro@uel.br

2 Master's student in the Graduate Program in Animal Science, UEL, Londrina, PR, Brazil. E-mail: amanda.pena@ hotmail.com

${ }^{3}$ Researcher, PhD, INRA UMR868, Mediterranean and Tropical Livestock Systems, SELMET, Montpellier, France. E-mail: eliel.gonzalez-garcia@inra.fr

* Author for correspondence
\end{abstract}

Received: May 27, 2020 - Approved: Nov. 04, 2020 
of poor BCS, Santa Inês ewes have the physiological capacity to adapt themselves to a negative energy balance similar to the periparturient period. It seems that irrespective of the BCS, ewes prioritized lactation and were able to produce enough milk to nurse their lambs accordingly.

Key words: Adaptability. Blood metabolites. Milk. Native breed. Nutrition. Sheep.

\section{Resumo}

Esta pesquisa teve como principal objetivo avaliar o desempenho de ovelhas Santa Inês de acordo com o escore de condição corporal ao parto. Foram usados dados de 135 ovelhas adultas com partos simples e seus respectivos cordeiros. As ovelhas foram divididas em três grupos: 1) Abaixo da média: ECC menor do que 2,5 pontos ( $n=44) ; 2$ ) Média: ECC entre 2,5 e 3,0 ( $n=53)$; e 3) Acima da média: ECC maior do que 3,0 ( $n=38$ ). A escala de ECC variou de 1 (muito magra) a 5 (muito gorda). Foram avaliados individualmente nas ovelhas o peso corporal, ECC, perfil metabólico e a produção e composição do leite, bem como o desempenho dos cordeiros até o desmame. O perfil metabólico foi avaliado nos dias $-7,+7$ e +60, com relação ao parto. Observou-se que ovelhas com ECC mais elevado foram também as mais pesadas, porém, não houve diferença entre os grupos para os pesos dos cordeiros ao nascimento e ao desmame (70 dias). Como não houve diferença na produção e composição do leite, os ganhos de peso médio diário para os cordeiros dos diferentes grupos de ECC também foram similares. O perfil metabólico (hemoglobina, proteína total, albumina, creatinina, ureia, glicose, $\beta$-hidroxibutirato, colesterol e aspartato aminotransferase - AST) também foi similar entre os grupos. Por outro lado, quando o perfil metabólico foi comparado entre as diferentes fases fisiológicas com relação ao parto, algumas diferenças foram observadas. Por exemplo, o $\beta$-hidroxibutirato foi maior durante o periparto, e a glicose foi maior na fase lactacional. Conclui-se que, mesmo em situação de ECC abaixo do ideal, ovelhas Santa Inês são capazes de se adaptar fisiologicamente aos períodos de balanço energético negativo, como no período de periparto. Ao que parece, independentemente do ECC, as ovelhas priorizam a lactação e são capazes de produzir leite em quantidade suficiente para amamentar adequadamente seus cordeiros.

Palavras-chave: Adaptabilidade. Leite. Metabólitos sanguíneos. Nutrição. Ovinos. Raça nativa.

\section{Introduction}

The Santa Inês is a Brazilian hair sheep breed originating from the northeast region of the country. This region is considered a harsh environment for animal production, mainly because of the high temperatures and low rainfall during the year (Ribeiro \& GonzálezGarcía, 2016; Hermuche et al., 2013). Therefore, animals from this breed are supposed to present rusticity for this kind of environment without reproductive seasonality. The breed is essentially exploited for meat production, but some producers and technicians have suggested the possibility of exploiting the breed for milk production (Ribeiro \& GonzálezGarcía, 2016; Ferreira et al., 2011). However, the development of this alternative requires research.

Several factors affect milk production and the general performance of ewes. In addition to the genetic potential, nutrition is one of the most important aspects to consider in animal production (Knapik, Ropka-Molik, \& Pieszka, 2017). To determine if an animal is well nourished, weight and body condition scores (BCS) are used (Kenyon, Maloney, \& Blache, 2014). Generally, a minimum BCS is attributed to 
specific physiological phases of an animal. For example, Kenyon et al. (2014) suggested that, at lambing, ewes should present a minimum of 2.5-3.0 points for the BCS, in a scale of up to 5.0 points. This score is required to produce good lactation and good reproduction indexes in the following reproduction season. The authors also stated that ewes should not have a BCS below 2.0 at weaning and should not have lost more than 1.0 unit of BCS during lactation. However, for Santa Inês ewes, successful reproduction can be achieved with lower BCS scores than those established for other meat breeds. This difference may be due to the breed being more rustic than the large breeds specialized for meat production.

The nutritional status of a flock can also be assessed by monitoring blood metabolites (Antunovic et al., 2017; Brondani, Lemes, Ferreira, Roll, \& Del Pino, 2016; GonzálezGarcía et al., 2011), using energy and protein indicators. The blood biochemical composition is an objective and precise way to diagnose the feed status in animal nutrition (Antunovic et al., 2011, 2017; Brondani et al., 2016). This is important because a negative nutritional balance is the main cause of most metabolic diseases (Brondani et al., 2016; Brozos, Mavrogianni, \& Fthenakis, 2011).

The objective of this paper was to evaluate the effects of different BSC of Santa Inês ewes entering the periparturient period on their BW and BCS changes, milk production and composition, metabolic profiles, and lamb performance until weaning. We hypothesized that the adaptive capacity of this breed enables it to compensate for the differences in BCS at lambing without compromising lamb performance until weaning.

\section{Material and Methods}

\section{Experimental site and animals}

The ewes selected for this experiment belonged to the main sheep flock of the Londrina State University's School Farm. This farm is located in Londrina, Paraná State, Brazil (2320'10" S; 5109'15" W; 610 meters above sea level). According to the Köppen Climatic Classification System, the region is classified as Cfa (a humid temperate climate with a hot summer) (Aparecido, Rolim, Richetti, Souza, \& Johann, 2016). The average annual temperature varies from 21.0 to $22.0^{\circ} \mathrm{C}$. The average temperature in January and February (the hottest months) is $24.5^{\circ} \mathrm{C}$, and in June and July (the coldest months) is $17.5^{\circ} \mathrm{C}$. Average annual rainfall varies from 1600 to $1800 \mathrm{~mm}$, with a maximum in January $(210 \mathrm{~mm})$ and minimum in August (50 mm) (Nitsche, Caramori, Ricce, \& Pinto, 2019).

A total of 135 observations, from six non-consecutive years, were used: 11 from 2007, 16 from 2009, 19 from 2010, 20 from 2011, 34 from 2014, and 35 from 2015. With very few exceptions, different Santa Inês ewes were used each year. Ewes came from a larger flock of about 80 reproductive females mated annually. Selection was based on multiparous, with one lamb, and four to eight teeth (permanent incisors). All procedures complied with all of the relevant animal welfare laws and guidelines.

\section{General management and nutrition}

Ewes were naturally mated for 45 days every year from March to April, at a ratio of 1 ram to 40 ewes, and lambing occurred from August to September. To correctly identify 
the day of mating, ink was placed on the sternum region of the rams. The mark on the croup was used to identify ewes and record the day of mating. Animals were maintained for the whole year under pasture conditions (Coast-cross - Cynodon dactylon (L.) Pers), in a six paddock rotational grazing system. However, during the winter season, from June to September, in addition to pasture, sheep received sorghum (Sorghum spp.) silage daily (at a rate of approximately $2.0 \mathrm{~kg} \mathrm{ewe}^{-1}$, natural matter basis). During lactation, the diet was supplemented daily with $0.5 \mathrm{~kg}$ per head of a concentrate feed containing $180 \mathrm{~g} \mathrm{~kg}^{-1}$ of crude protein (CP) and $2.2 \mathrm{Mcal} \mathrm{kg}^{-1}$ of metabolizable energy (ME), in dry matter (DM). The farm did not vary the annual diet provided to the ewes, therefore the estimate of the feedstuff chemical composition was analyzed using a single representative sample (presented in Table 1; Mangilli, 2016).

\section{Traits evaluated}

The individual body weights (BW), BCS, milk production and composition, and metabolic profiles were monitored. Blood samples were also collected for further biochemical analyses. Ewes were weighed and BCS estimated at lambing and weaning. Weaning was performed at 70 days after parturition. The lambs were also weighed at birth and at weaning. The productivity of the ewes was measured by the ratio of $\mathrm{kg}$ of lambs to the $\mathrm{kg}$ of ewes at weaning. The procedures suggested by Russel (1984) were followed for ewe body scoring. The BCS varied in a scale ranging from 1 (very thin) to 5 (very fat), with the possibility of 0.5 increment units in classes up to 4. Therefore, the BCS functioned as a 9-point scale.

\section{Table 1}

\section{Estimated chemical composition of various ewe feedstuff}

$\begin{array}{lccccccc}\text { Feedstuff } & \begin{array}{c}\mathrm{DM} \\ \left(\mathrm{g} \mathrm{kg}^{-1} \mathrm{NM}\right)\end{array} & \begin{array}{c}\mathrm{CP} \\ \left(\mathrm{g} \mathrm{kg}^{-1} \mathrm{DM}\right)\end{array} & \begin{array}{c}\mathrm{EE} \\ (\mathrm{g} \mathrm{kg}-1 \mathrm{DM})\end{array} & \begin{array}{c}\mathrm{NDF} \\ \left(\mathrm{g} \mathrm{kg}^{-1} \mathrm{DM}\right)\end{array} & \begin{array}{c}\text { ADF } \\ \left(\mathrm{g} \mathrm{kg}^{-1} \mathrm{DM}\right)\end{array} & \begin{array}{c}\mathrm{MM} \\ \left(\mathrm{g} \mathrm{kg}^{-1} \mathrm{DM}\right)\end{array} & \begin{array}{c}\mathrm{TDN} \text { 1 } \\ \left(\mathrm{g} \mathrm{kg}^{-1} \mathrm{DM}\right)\end{array} \\ \text { Coast-cross } & 352.8 & 142.9 & 18.9 & 677.8 & 319.0 & 91.4 & 642.3 \\ \text { Sorghum silage } & 300.3 & 77.8 & 30.8 & 595.3 & 345.0 & 59.5 & 621.9 \\ \text { Corn grain } & 891.8 & 95.8 & 42.1 & 334.1 & 18.1 & 11.4 & 825.8 \\ \text { Soybean meal } & 894.5 & 522.2 & 24.2 & 218.4 & 77.7 & 61.5 & 827.5 \\ \text { Soybean oil } & 993.0 & - & 990.0 & - & - & 5.0 & 1950.0 \\ \text { Calcarium } & 990.0 & - & - & - & - & 990.0 & -\end{array}$

DM, dry matter; $C P$, crude protein; EE, ether extract; NDF, neutral detergent fiber; ADF, acid detergent fiber; MM, mineral matter; TDN, total digestible nutrients.

${ }^{1}$ According to Kearl (1982): \%TDN Silage and pasture $=-21.9391+1.0538 \% C P+0.9736 \% E N N+3.0016 \% E E+0.4590$ \%CF; \%TDN Energetic foods $=40.2625+0.1969 \%$ CP + 0.4228 \%ENN + 1.1903 \%EE - 0.1379 \%CF; \%TDN Protein foods $=40.3227+0.5398 \% C P+0.4448 \% E N N+1.4218 \% E E-0.7007 \% C F$.

Source: Mangilli (2016) 


\section{Milk production and composition}

Milk production was evaluated every 14 days during lactation. The milking procedure followed the methodology described by Podleskis et al. (2005) and consisted of separating lambs from their mothers for a period of $4 \mathrm{~h}$, from $0800 \mathrm{~h}$ to $1200 \mathrm{~h}$, after the udder was completely emptied. Ewes received $1 \mathrm{IU}$ of oxytocin, and then hand milked (Ribeiro et al., 2004). Milk production was adjusted for $2400 \mathrm{~h}$. Average milk production was calculated using the average of five milking days $(7,21,35,49$, and 63 d). Milk samples (40 $\mathrm{mL}$ ) were also collected at milking and sent to the laboratory for analyses of the total solids, fat, crude protein, and lactose (Instituto Adolfo Lutz [IAL], 1985). The milk samples were placed in appropriate tubes containing bronopol. The tubes were immediately packed in isothermal boxes with ice and sent to the laboratory. Milk productivity was measured as $\mathrm{mL}$ of milk produced per kg of ewe at lambing.

\section{Blood sampling and analyses}

On three specific days, blood samples were individually collected prior to the first morning feed. The blood samples were collected: 7 days before lambing (day -7), 7 days after lambing (day +7 ), and on the 60th day of lactation (day +60 ). To ensure that the first blood harvest was performed on day -7 , the collection took place on day 140 after mating. This collection date was based on the previous observations of the flock, the average pregnancies were 147 days. Samples were taken by jugular venipuncture with $25 \times 7$ $\mathrm{mm}$ needles. For each collection, a total of 15 $\mathrm{mL}$ of blood was sampled in two vacutainer tubes: $10 \mathrm{~mL}$ without anticoagulant (to obtain serum) and $5 \mathrm{~mL}$ in a tube containing sodium fluoride (to obtain plasma). The samples without anticoagulant were centrifuged (3500 rpm for $5 \mathrm{~min}$ ) and serum was collected and stored in $1 \mathrm{~mL}$ Eppendorf tubes. Samples were frozen at $-20{ }^{\circ} \mathrm{C}$ until required for biochemical analyses. The glucose levels were analyzed upon arrival at the laboratory using the plasma blood samples.

Blood samples were analyzed using specific kits. Total protein and serum albumin concentrations were measured using the colorimetric technique by the bromocresol green method (Analisa ${ }^{\circledR}$, Minas Gerais, Brazil). Creatinine was measured using the kinetic enzymatic method (Imunotech ${ }^{\circledR}$, São Paulo, Brazil). Urea was measured using the kinetic enzymatic method (Imunotech ${ }^{\circledR}$, São Paulo, Brazil). Plasma glucose and serum cholesterol concentrations were determined by an enzymatic colorimetric method (Analisa ${ }^{\circledR}$, Minas Gerais, Brazil). $\beta$-hydroxybutyrate was measured by a kinetic enzymatic method

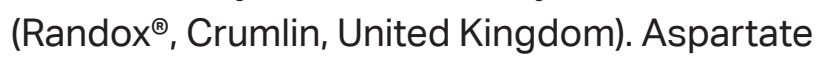
aminotransferase enzyme was measured by a kinetic enzymatic method (Imunotech ${ }^{\circledR}$, São Paulo, Brazil).

Total protein, albumin, glucose, and cholesterol analyses were performed using the semi-automatic biochemical analyzer BioPlus 2000 (Bioplus ${ }^{\circledR}$, São Paulo, Brazil). The hemoglobin, creatinine, urea, and aspartate aminotransferase enzyme analyses were determined using an automatic biochemical analyzer, Mindray BS120 (Mindray ${ }^{\circledR}$, São Paulo, Brazil). The $\beta$-hydroxybutyrate was measured with the aid of an automatic device Dimension RxLMax (Siemens ${ }^{\circledR}$, São Paulo, Brazil). 


\section{Statistical analyses}

For the analyses, at lambing ewes were classified by their BCS into three groups. The groups were Below Average $=$ BCS $<2.5$ (44 ewes), Average = BCS $2.5-3.0$ (53 ewes), and Above Average $=$ BCS $>3.0$ (38 ewes). The collected data was subjected to an analysis of variance using the Mixed procedure of SAS (Statistical Analysis System, version 9.1). The following mathematical model was used:

$Y_{i j k l}=\mu+B_{i}+$ Year $_{j}+S_{k}+\left(B \times Y_{\text {Year }}\right)_{i j}+(B \times S)_{i k}+$ $(\text { Year } \times \mathrm{S})_{\mathrm{jk}}+\mathrm{Ewe}_{\mathrm{l}}+\varepsilon_{\mathrm{ijkl}}$

Where $\mathrm{Y}_{\mathrm{ijkl}}=$ observed values for each trait, $\mu=$ overall mean, $B_{i}=$ fixed effect of the "i" BCS, Year = fixed effect of the " $\mathrm{j}$ " year, $\mathrm{S}_{\mathrm{k}}=$ fixed effect of the " $k$ " sex of the lamb, $\left(B \times\right.$ Year $_{\mathrm{ij}}=$ interaction between the "i" BCS with the "j" year, $(B \times S)_{i k}=$ interaction between the " $i$ " BCS with the " $k$ " sex of the lamb, $(\text { Year } \times S)_{j \mathrm{k}}=$ interaction between the "j" year with the " $k$ " sex of the lamb, Ewe $=$ random effect of the "I" ewe, and $\varepsilon_{\mathrm{ijkl}}=$ random error associated with each value.

To investigate the effect of sex, the results of the F-test was used to identify any mean separation. A t-test was used to determine any significant BCS effects. A $P$ value of 0.05 was considered statistically significant $(P \leq 0.05)$.

To evaluate the physiological phase of the metabolic profile, the effect of day $(-7,+7$, +60 ) was included in the model. For this model, the data were first tested for sphericity using Mauchly's Test of Sphericity. The analysis demonstrated that the sphericity assumption was not violated. The $P$ value assumed for statistical differences was 0.05 , and for mean separation, the t-test was used.

\section{Results and Discussion}

The effect of year was significant $(\mathrm{P}<$ 0.05) for the studied variables. However, since there was no interaction with the other effects, and its use in the statistical model was mainly aimed at correcting the data, the results for year are not presented. The interactions tested in the statistical model were not significant; the results of BCS, sex of lambs, and physiological phase are presented independently in the tables. The average BCSs at lambing for the three groups were $1.9,2.8$, and 3.5 , respectively (Table 2). 


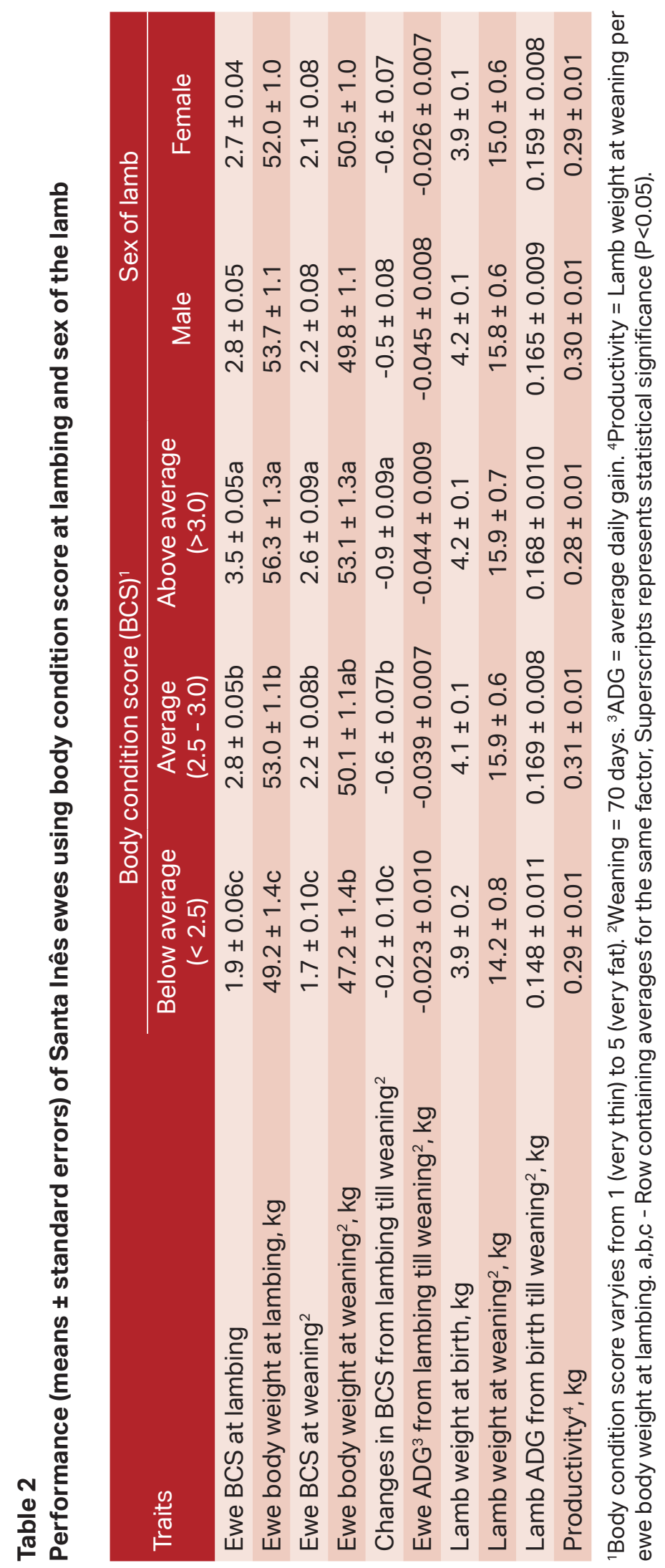


Ewes with the greatest and poorest BCSs at lambing were also the heaviest and lightest ones, respectively (Table 2). The same tendency was observed for the BW of the ewes at weaning. The average loss of daily weight was not significantly different among the BCS groups. However, a pattern emerged, the higher the BCS and the BW at lambing, the greater the BW and BCS losses from lambing to weaning. Proportionally, as ewes progressed to weaning, ewes from the below average BCS group lost $4.1 \%$ of BW and $10.5 \%$ of BCS, while ewes from the above average BCS group lost $5.7 \%$ of BW and $25.7 \%$ of BCS.

Despite the observed differences in BCS and BW of the ewes, birth weight, lambs weight at weaning, and the average daily gain (ADG) of the lambs did not differ among the ewe BCS groups (Table 2). Due to the variation in BW, a comparison on productivity was implemented (i.e., kg of lambs produced by $\mathrm{kg}$ of ewes at weaning). The three BCS groups demonstrated no significant difference in productivity (i.e., from 0.28 to 0.31 ; Table 2 ).

Sex of the lambs did not influence either the BCS or BW of their mothers at lambing. Sex of the lambs also did not influence the changes in BCS and BW from lambing to weaning. The same was observed for the performance of the lambs, where male and female lambs had similar BW at birth and at weaning (Table 2).

Ewes of the three BCS groups had similar milk production with milk of similar compositions (Table 3). Milk productivity (daily milk production per $\mathrm{kg}$ of ewe BW at lambing) did not vary among the BCS groups. On the other hand, ewes that had male lambs produced $26.4 \%$ more milk than ewes with female lambs, producing more milk daily per kg of BW (24.3 vs. 19.5 mL kg-1 of BW; Table 3). However, milk composition did not differ between ewes bearing male or female lambs.

\section{Table 3}

Milk production (up to 63 days of lactation) and composition (means \pm standard errors) of Santa Inês ewes using body condition score at lambing and sex of the lamb

\begin{tabular}{|lccccc} 
& \multicolumn{2}{c}{ Body condition score $(\mathrm{BCS})^{1}$} & \multicolumn{2}{c}{ Sex of lamb } \\
\cline { 2 - 6 } \multicolumn{1}{c}{ Traits } & $\begin{array}{c}\text { Below } \\
\text { average } \\
(<2.5)\end{array}$ & $\begin{array}{c}\text { Average } \\
(2.5-3.0)\end{array}$ & $\begin{array}{c}\text { Above } \\
\text { average } \\
(>3.0)\end{array}$ & Male & Female \\
Average daily milk production, $\mathrm{mL}$ & $1099 \pm 91$ & $1180 \pm 69$ & $1202 \pm 83$ & $1296 \pm 73 a$ & $1025 \pm 67 \mathrm{~b}$ \\
\hline Fat, $\mathrm{g} \mathrm{kg}^{-1}$ & $75.0 \pm 3.0$ & $76.0 \pm 2.0$ & $72.0 \pm 3.0$ & $76.0 \pm 2.0$ & $73.0 \pm 2.0$ \\
\hline Protein, $\mathrm{g} \mathrm{kg}^{-1}$ & $50.0 \pm 1.0$ & $47.0 \pm 1.0$ & $47.0 \pm 1.0$ & $48.0 \pm 1.0$ & $48.0 \pm 1.0$ \\
\hline Lactose, $\mathrm{g} \mathrm{kg}^{-1}$ & $50.0 \pm 1.0$ & $52.0 \pm 0.0$ & $52.0 \pm 1.0$ & $51.0 \pm 1.0$ & $51.0 \pm 0.0$ \\
\hline Total solids, $\mathrm{g} \mathrm{kg}^{-1}$ & $188.0 \pm 3.0$ & $190.0 \pm 3.0$ & $185.0 \pm 3.0$ & $189.0 \pm 3.0$ & $186.0 \pm 2.0$ \\
Productivity ${ }^{2} \mathrm{~mL} \mathrm{~kg}^{-1}$ & $21.8 \pm 1.7$ & $22.6 \pm 1.3$ & $21.1 \pm 1.6$ & $24.3 \pm 1.4 \mathrm{a}$ & $19.5 \pm 1.2 \mathrm{~b}$
\end{tabular}

${ }^{1}$ Body condition score varyies from 1 (very thin) to 5 (very fat). ${ }^{2}$ Productivity $=$ Average daily milk production per unit body weight at lambing. ${ }^{a, b}$ : Superscripts represent significant variation $(P<0.05)$. 
The energy and the protein metabolic blood profile indicators did not differ among the three groups of BCS at lambing (Table 4).
Similarly, they did not vary between ewes that had male or female lambs (Table 4).

\section{Table 4}

Metabolic profile (means \pm standard errors) of Santa Inês ewes using body condition score at lambing and sex of the lamb

\begin{tabular}{|c|c|c|c|c|c|}
\hline \multirow[b]{2}{*}{ Traits } & \multicolumn{3}{|c|}{ 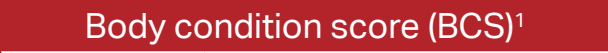 } & \multicolumn{2}{|c|}{ Sex of lamb } \\
\hline & $\begin{array}{l}\text { Below } \\
\text { average } \\
(<2.5)\end{array}$ & $\begin{array}{c}\text { Average } \\
(2.5-3.0)\end{array}$ & $\begin{array}{c}\text { Above } \\
\text { average } \\
(>3.0)\end{array}$ & Male & Female \\
\hline Hemoglobin, $\mathrm{g} \mathrm{dL}^{-1}$ & $11.3 \pm 0.8$ & $10.7 \pm 0.3$ & $9.8 \pm 0.4$ & $10.9 \pm 0.3$ & $10.3 \pm 0.5$ \\
\hline Total protein, $\mathrm{g} \mathrm{dL}^{-1}$ & $6.6 \pm 0.2$ & $6.8 \pm 0.1$ & $6.9 \pm 0.1$ & $6.7 \pm 0.1$ & $6.7 \pm 0.1$ \\
\hline Albumin, $\mathrm{g} \mathrm{dL}^{-1}$ & $2.6 \pm 0.1$ & $2.7 \pm 0.1$ & $2.7 \pm 0.1$ & $2.7 \pm 0.0$ & $2.7 \pm 0.1$ \\
\hline Creatinine, $\mathrm{mg} \mathrm{dL}^{-1}$ & $0.96 \pm 0.06$ & $1.06 \pm 0.03$ & $1.04 \pm 0.03$ & $1.03 \pm 0.02$ & $1.01 \pm 0.04$ \\
\hline Urea, mg dL-1 & $18.3 \pm 1.7$ & $18.1 \pm 0.6$ & $20.1 \pm 0.7$ & $19.1 \pm 0.6$ & $18.6 \pm 1.2$ \\
\hline Glucose, $\mathrm{mg} \mathrm{dL}^{-1}$ & $55.0 \pm 2.4$ & $54.2 \pm 0.8$ & $54.2 \pm 1.0$ & $54.8 \pm 0.8$ & $54.2 \pm 1.6$ \\
\hline$\beta$-hydroxibutyrate, $\mathrm{mmol} \mathrm{L}^{-1}$ & $0.21 \pm 0.04$ & $0.28 \pm 0.02$ & $0.24 \pm 0.02$ & $0.26 \pm 0.02$ & $0.22 \pm 0.03$ \\
\hline Cholesterol, mg dL-1 & $69.2 \pm 3.2$ & $66.3 \pm 1.8$ & $65.3 \pm 2.0$ & $66.8 \pm 1.6$ & $67.1 \pm 2.2$ \\
\hline Aspartate aminotransferase - AST, IU L-1 & $79.1 \pm 6.2$ & $85.5 \pm 2.5$ & $74.8 \pm 2.7$ & $82.8 \pm 2.3$ & $76.8 \pm 4.2$ \\
\hline
\end{tabular}

${ }^{1}$ Body condition score varyies from 1 (very thin) to 5 (very fat).

The metabolic profile tested three physiological stages, differences were observed for glucose, $\beta$-hydroxibutyrate, cholesterol, hemoglobin, total protein, and for the enzyme AST (Table 5). Glucose levels and AST were lower in late gestation than in lactation. On the other hand, $\beta$-hydroxibutyrate and hemoglobin were lower in late lactation $(+60 \mathrm{~d})$ than in both the late gestation $(-7 \mathrm{~d})$ and at the beginning of lactation $(+7 \mathrm{~d})$. Total protein levels peaked at the beginning of lactation. The cholesterol concentration was lower during late gestation and at the beginning of lactation when compared to late lactation.

The precise reason(s) why the ewes who were receiving similar feed, with good teeth condition, and apparently good health condition, presented different BCS at lambing remainsunknown. Althoughthereisno definitive answer, some possibilities are suggested, such as the dominant behavior of some animals may have restricted access for the remaining ewes to the best feeds (both in the pasture and in the feeding troughs) as observed by Virgilio and Morales (2016). There is also the possibility of genetic differentiation between individuals in the efficiency of utilizing ingested nutrients (Gagloev, Babushkin, \& Negreeva, 2019), which can alter nutrient deposition in animal tissues. This can occur in individuals of the same breed and physiological condition, as in the present study. Yang et al. (2020) also identified that nutritional requirements may vary between different groups. 


\section{Table 5}

Metabolic profile (means \pm standard errors) of Santa Inês ewes according to physiological phase

\section{Traits}

Hemoglobin, $\mathrm{g} \mathrm{dL}^{-1}$

Total protein, $\mathrm{g} \mathrm{dL}^{-1}$

Albumin, $\mathrm{g} \mathrm{dL}^{-1}$

Creatinine, $\mathrm{mg} \mathrm{dL}^{-1}$

Urea, $\mathrm{mg} \mathrm{dL}^{-1}$

Glucose, $\mathrm{mg} \mathrm{dL}^{-1}$

Beta-hydroxibutyrate, $\mathrm{mmol} \mathrm{L}^{-1}$

Cholesterol, $\mathrm{mg} \mathrm{dL}^{-1}$

Aspartate aminotransferase - AST, IU L $L^{-1}$

\section{Physiological phase (day) ${ }^{1}$}

$-7$

$10.1 \pm 0.3 b$

$6.58 \pm 0.10 b$

$2.57 \pm 0.05$

$1.04 \pm 0.03$

$20.9 \pm 1.0$

$51.4 \pm 1.1 \mathrm{~b}$

$0.28 \pm 0.02 a$

$64.2 \pm 1.6 \mathrm{~b}$

$70.8 \pm 2.4 \mathrm{~b}$

$+7$

$+60$

$9.3 \pm 0.3 c$

$11.3 \pm 0.3 a$

$6.86 \pm 0.10 a$

$2.67 \pm 0.05$

$1.01 \pm 0.03$

$19.5 \pm 1.0$

$56.3 \pm 1.1 \mathrm{a}$

$0.26 \pm 0.02 a$

$60.1 \pm 1.6 b$

$84.6 \pm 2.7 \mathrm{a}$
$6.60 \pm 0.10 \mathrm{ab}$

$2.69 \pm 0.05$

$1.01 \pm 0.04$

$18.6 \pm 1.1$

$55.2 \pm 1.3 a$

$0.23 \pm 0.02 b$

$76.7 \pm 1.6 a$

$87.0 \pm 2.7 a$

${ }^{1}$ The reference is day 0 (lambing). ${ }^{a, b, c}$ - Averages in the same row followed by different letters differ significantly $(\mathrm{P}<0.05)$.

Kenyon et al. (2014) reported that the live weight of a ewe is a combination of both body size and condition, therefore live weight may not necessarily be a good indicator of an animal's body condition. Nevertheless, there are well-established positive relationships between BCS and live weight. However, in the present study, we identified that the differences in BW at lambing among the three BCS groups were mainly due to differences in muscle and fat deposition in the body, and not due to variations in body size. However, during lactation, ewes that had higher BCS at lambing were deploying greater mobilization of body reserves to maintain milk production. Consequently, they lost more BCS at this stage.

Generally, poor BCS is related to deficient nutrition. Castro etal. (2012) observed that ewes under energy restrictions ( 2.2 and 2.0 Mcal of ME kg-1 of DM) during the late gestation and during lactation were lighter at lambing and lost weight and BCS prior to weaning. Conversely, ewes with high energy intake (2.4
Mcal of ME $\mathrm{kg}^{-1}$ of DM) were heavier and did not lose weight during this period. However, contrary to Castro et al. (2012), ewes in our experiment were not subject to undernutrition and received the same feed management.

When diet does not meet the energy requirements or when the energy balance is negative due to a specific physiological stage, the organism mobilizes body reserves (González-García et al., 2014, 2015). This can happen during periods of feed deficiency or in periods of increased requirements, such as gestation and lactation. In these cases, higher concentrations of $\beta$-hydroxybutyrate are recorded (Araujo et al., 2014; Brozos et al., 2011). Research dictates that values higher than 0.7 and $0.8 \mathrm{mmol} \mathrm{L}^{-1}$ indicate a negative energy balance. In the present study, the values for the three BCS groups were consistently lower than $0.7 \mathrm{mmol} \mathrm{L}^{-1}$.

Araujo et al. (2014) did not observe differences in $\beta$-hydroxybutyrate among non-pregnant, single gestations, and twin 
gestations of Santa Inês ewes. The means in our study are close to those reported by Araujo et al. (2014). Our results are comparable to the means reported by Ortunho, Marçal, Carvalho, Carli and Beline (2016), investigating Suffolk sheep and by Nasciutti et al. (2012), investigating healthy Santa Inês ewes with BCS between 2.1 and 2.4 during the peripartum period. On the other hand, Santos et al. (2011) reported average values for $\beta$-hydroxybutyrate of $0.77 \mathrm{mmol} \mathrm{L}^{-1}$ from ewes with pregnancy toxaemia; Lotfollahzadeh, Zakian, TehraniSharif and Watson (2016) measured values greater than $0.86 \mathrm{mmol} \mathrm{L}^{-1}$ from ewes with inadequate energy intakes and found no significant correlation between BCS and serum concentrations of $\beta$-hydroxybutyrate.

The most surprising result is the consistent performance of the ewes with the lowest BCS at lambing. Although they had lower body reserves during the lactation period, they were able to keep their metabolites at levels similar to those of ewes with higher BCS at lambing. At the same time, there was only limited BCS reductions in this period; a period classically considered the most demanding for dams (Duehlmeier, Fluegge, Schwert, Parvizi, \& Ganter, 2011). According to the authors, ewes have a great capacity to deal with nutritional deficiencies. From our results, it could be hypothesized that the maintenance requirements may vary according to BCS (i.e., basal metabolism and maintenance requirements are concomitantly adjusted).

The observed values for the metabolic profile are, in most cases, in accordance with the reference values considered by Nasciutti et al. (2012) and Santos et al. (2011). Values are close to those presented by Cardoso et al. (2010), who studied Santa Inês ewes from
-30 to +30 days from lambing. The exception is creatinine, where the values observed in this study are lower than the reference values for sheep, 1.2 - $1.9 \mathrm{mg} \mathrm{dL}^{-1}$ (Santos et al., 2011). However, our results are quite close to the averages (1.06 - $1.08 \mathrm{mg} \mathrm{dL}^{-1}$ ) reported by Ortunho et al. (2016) for Suffolk ewes, who were in good health and receiving adequate nutrition.

According to Nascimento et al. (2015), the production of creatinine is nearly constant and not affected by diet. However, when there is a marked decrease in muscle mass, creatinine levels may reduce. Creatinine is generally used to monitor kidney function because when there is serious kidney damage (causing a decrease in the glomerular filtration rate), creatinine levels are above the normal physiological values. Souto et al. (2019) reported that high creatinine values could be observed in ewes with pregnancy toxemia, therefore, ewes with renal impairment. However, this is more likely to occur in ewes with a high body condition score. Our results indicated that the ewes did not have any kidney problems.

In the evaluation of protein status, low albumin, urea, and total protein values, results suggest an inadequate protein balance, which is an indicator of long periods of protein restriction. In the present study, values for albumin, total protein, and urea $\left(2.6 \mathrm{~g} \mathrm{dL}^{-1} ; 6.6\right.$ $\mathrm{g} \mathrm{dL}^{-1}$ and $18 \mathrm{mg} \mathrm{dL}^{-1}$, respectively) are at the threshold of the reference values for sheep, as reported by Santos et al. (2011). Albumin and total protein were higher than the average values presented by Nasciutti et al. (2012) for Santa Inês ewes with poor BCS during the peripartum period. With respect to the energy status, all parameters are within the normal range for sheep in late pregnancy and lactation, 
as shown by Nasciutti et al. (2012) and Santos et al. (2011). The results indicate that energy requirements of the ewes were met.

By keeping their metabolic profile in normal levels (irrespective of the BCS at lambing), ewes in late gestation and lactation were able to produce enough milk, and milk with a good composition, to allow good lamb performance. The lambs demonstrated no differences in weight and weight gain up to weaning. Kenyon et al. (2014) reported that up to one-third of the milk produced by a ewe, especially in the first four weeks of lactation, is due to the mobilization of body reserves. However, when lactating ewes have access to adequate feed, BCS has no impact on milk production. This finding was demonstrated in the present study.

The average milk production for the three BCS groups ( $\left.1160 \mathrm{~mL} \mathrm{day}^{-1}\right)$ was greater than the average observed by Castro et al. (2012) (607 mL day $\left.{ }^{-1}\right)$, at 57 days of lactation for crossbred Santa Inês ewes. The average milk production in our study was also higher than the production cited by Ferreira et al. (2011) for Santa Inês ewes at 17 weeks of lactations $\left(1005 \mathrm{~mL}\right.$ day $\left.^{-1}\right)$. The estimated averages support the possibility of exploiting Santa Inês ewes for milk production. Daily milk production in dairy Lacaune ewes varied from 1.11 to $1.25 \mathrm{~kg}$ at 168 days of lactation (González-García et al., 2015). The amount of fat (74.5 $\mathrm{g} \mathrm{kg}^{-1}$ of milk) was greater than that observed by Ferreira et al. (2011) for Santa Inês ewes (66.0 $\mathrm{g} \mathrm{kg}^{-1}$ of milk). However, Ferreira et al. (2011) reported values for protein $\left(51 \mathrm{~g} \mathrm{~kg}^{-1}\right.$ of milk) very close to the present study (48 $\mathrm{g}$ $\mathrm{kg}^{-1}$ of milk).

The results between ewes nursing male or female lambs were quite similar, with the exception of milk production and milk productivity. In both cases, ewes with male lambs had greater averages. However, this higher milk production did not influence the performance of the lambs, as there were no differences in ADG when compared to the females. Al-Qasimi, Abbas and Al-Khauzai (2020) also found higher milk production in ewes that had given birth to male lambs. According to the authors, this was due to the larger size of the males at birth, having a higher nutritional demand, which stimulated the mothers to produce more milk. This type of stimulus is easily observed when comparing ewes with twin and simple deliveries, where, if nutrition is adequate, ewes with twins produce more milk (Abecia \& Palacios, 2018; Al-Qasimi et al., 2020). On the other hand, Abecia and Palacios (2018) observed that sheep with female lambs produced more milk than those with male lambs. According to the authors, some of the differences in milk production originate in pregnancy as the mammary gland develops. This development is mediated by the neuroendocrine system. Among the various hormones, that influence mammary gland development is the placental lactogen, its production is greater than the weight of the placenta, which occurs in larger fetuses and in twins. Contrarily, Ahmed et al. (2016) observed gender influences on lamb birth weights, but not on sheep milk production.

For the different physiological stages, it can be observed in the literature that during late gestation and mainly during the beginning of lactation, there is a great increase in nutrient requirements (Duehlmeier et al., 2011). During these phases, it is normal to observe a negative nutritional balance accompanied by changes in metabolic indicators (Raoofi, Jafarian, Safi, \& Vatankhah, 2013). The present research 
demonstrated that the $\beta$-hydroxibutyrate was greater during these two phases (during late gestation and beginning of lactation) and the cholesterol was lower when compared to +60 days of lactation. At the same time, hemoglobin and total protein levels were higher at the beginning of lactation $(d+7)$.

Our results agreed partially with those observed by Antunovic et al. (2011). These authors observed that the blood metabolic profile differed for ewes during the different physiological periods. They observed higher concentrations of urea and lower concentrations of glucose, LDL-cholesterol, total protein, and albumin during lactation, when compared to non-pregnant and late gestation ewes. The authors concluded that the ewes were subjected to feed deficiency during the lactation phase.

According to Antunovic et al. (2011), in lactating ewes, glucose is used for milk lactose synthesis, and if the intake of nutrients during this phase is not sufficient, blood glucose levels tend to decrease. During late gestation, glucose is also mobilized for fetal development. Araujo et al. (2014) observed higher values for glucose only at lambing. According to the authors, this may be related to higher concentrations of glucocorticoids and glucagon, both of which are involved in the mobilization of hepatic glycogen. Antunovic et al. (2011) also stated that the cholesterol decreases during early lactation, are due to increased requirements and/or a negative energy balance. They observed an increased hemoglobin content in ewes during the late gestation period, suggesting it was due to increased oxygen demand and higher metabolic rate during gestation.
The enzyme AST is related to the metabolism of the liver, and higher concentrations may be due to insufficient feed intake (Lotfollahzadeh et al., 2016; Antunovic et al., 2011) or altered liver functions related to pregnancy toxemia (Moreira, Assis, Lima, Facury, \& Borges, 2019). AST averages observed in the present study are within the normal reference values of Nasciutti et al. (2012) and Santos et al. (2011).

The three BCS values resulted in practically no changes in the metabolic profile of the ewes. Some differences were observed between the physiological stages; however, these changes were of low magnitude and within the range of the reference values for the species. This result may be because the ewes were of simple gestation and birth and had received adequate nutritional conditions to avoid an accentuated negative energy balance.

\section{Conclusion}

A Santa Inês ewe, considered in good health and receiving adequate nutrition, is able to maintain their metabolic status, produce milk with good quality, and consequently lambs with good average weight daily gains, if they have a body condition score between 1.9 and 3.5 at lambing. Under the study conditions, it seems that irrespective of the body condition score, ewes prioritized lactation and were able to produce enough milk to nurse their lambs accordingly.

\section{Acknowledgements}

The authors are grateful for the financial support of CNPq and the Fundação Araucária. 


\section{References}

Abecia, J. A., \& Palacios, C. (2018). Ewes giving birth to female lambs produce more milk than ewes giving birth to male lambs. Italian Journal of Animal Science, 17(3), 736-739. doi: 10.1080/1828051X.2017.14 15705

Ahmed, M. H., Salem, A. Z. M., Olafadehan, O. A., Kholif, A. E., Rivero, N., Mariezcurrena, M. A.,... Almaz, A. H. A. (2016). Effect of pre- and post-partum dietary crude protein level on the performance of ewes and their lambs. Small Ruminant Research, 136, 221-226. doi: 10.1016/j. smallrumres.2016.02. 002

Al-Qasimi, R. H., Abbas, S. M., \& Al-Khauzai, A. L. D. (2020). Effect of breed and some non - genetic factors on milk production and some proportions of its chemical components in two breeds of local sheep. Qadisiyah Journal for Agriculture Sciences, 10(1), 227-231. doi: 10.33794/ qjas.Vol10.Iss1.102

Antunovic, Z., Novoselec, J., Sawerwein, H. Speranda, M., Vegara, M., \& Pavic, M. (2011). Blood metabolic profile and some hormones concentration in ewes during different physiological status. Bulgarian Journal of Agricultural Science, 17(5), 687-695.

Antunovic, Z., Novoselec, J., Šperanda, M., Steiner, Z., Ćavar, S., Pavlović, N.... Klir, Z. (2017). Monitoring of blood metabolic profile and milk quality of ewes during lactation in organic farming. Mljekarstvo, 67(4), 243-252. doi: 10.15567/mljekarstvo. 2017.0401

Aparecido, L. E. O., Rolim, G. S., Richetti, J., Souza, P. S., \& Johann, J. A. (2016).
Köppen, Thornthwaite and Camargo climate classifications for climatic zoning in the State of Paraná, Brazil. Ciência e Agrotecnologia, 40(4), 405-417. doi: 10.1590/1413-70542016404003916

Araujo, C. A. S. C., Nikolaus, J. P., Morgado, A. A., Monteiro, B. M., Rodrigues, F. A. M. L.,... Sucupira, M. C. A. (2014). Perfil energético e hormonal de ovelhas Santa Inês do terço médio da gestação ao pósparto. Pesquisa Veterinária Brasileira, 34(12), 1251-1257. doi: 10.1590/S0100736X2014001200019

Brondani, W. C., Lemes, J. S., Ferreira, O. G. L., Roll, V. F. B., \& Del Pino, F. A. B. (2016). Perfil metabólico de ovelhas em gestação. Archivos de Zootecnia, 65(249), 1-6. doi: 10.21071/az.v65i249.449

Brozos, C., Mavrogianni, V. S., \& Fthenakis, G. C. (2011). Treatment and Control of peri-parturient metabolic diseases: pregnancy toxemia, hypocalcemia, hypomagnesemia. Veterinary Clinics: Food Animal Practice, 27(1), 105-113. doi: 10.1016/j.cvfa.2010.10.004

Cardoso, E. C., Oliveira, D. R., Dourado, A. P., Araújo, C. V., Ortalani, E. L., \& Brandão, F. Z. (2010). Peso e condição corporal, contagem de OPG e perfil metabólico sanguíneo de ovelhas da raça Santa Inês no periparto, criadas na região da Baixada Litorânea do Estado do Rio de Janeiro. Revista Brasileira de Ciência Veterinária, 17(2), 77-82. doi: 10.4322/rbcv.2014.148

Castro, F. A. B., Ribeiro, E. L. A., Mizubuti, I. Y., Silva, L. D. F., Barbosa, M. A. A. F., Sousa, C. L.,... Koritiaki, N. A. (2012). Influence of pre and postnatal energy restriction on the productive performance of ewes and 
lambs. Revista Brasileira de Zootecnia, 41(4), 951-958. doi: 10.1590/S151635982012000400017

Duehlmeier, R., Fluegge, I., Schwert, B., Parvizi, N., \& Ganter, M. (2011). Metabolic adaptations to pregnancy and lactation in German Blackheaded Mutton and Finn sheep ewes with different susceptibilities to pregnancy toxaemia. Small Ruminant Research, 96(2-3), 178-184. doi: 10.1016/j. smallrumres.2010.12. 002

Ferreira, M. I. C., Borges, I., Macedo, G. L., Jr., Rodriguez, N. M., Penna, C. F. A. M., Souza, M. R.,... Cavalcanti, L. F. (2011). Produção e composição do leite de ovelhas Santa Inês e mestiças Lacaune e Santa Inês e desenvolvimento de seus cordeiros. Arquivo Brasileiro de Medicina Veterinária e Zootecnia, 63(2), 530-533. doi: 10.1590/ S0102-09352011000200040

Gagloev, A. C., Babushkin, V. A., \& Negreeva, A. N. (2019). Nutrient utilization in buck lambs with different genotypes. Amazonia investiga, 8(22), 522-529.

González-García, E., Debus, N., Hassoun, P., Camous, S., Aurel, M. R., Bocquier, F., \& Barillet, F. (2011). Blood metabolites and hormones as potential markers of body reserves dynamic and energetic balance in ruminants. Journal of Animal Science, 89(Suppl. 1), 443.

González-García, E., Figuereido, V. G., Foulquie, D., Jousserand, E., Autran, P., Camous, S.,... Jouven, M. (2014). Circannual body reserve dynamics and metabolic profile changes in Romane ewes grazing on rangelands. Domestic Animal Endocrinology, 46(1), 37-48. doi: 10.1016/j.domaniend.2013.10.002
González-García, E., Tesniere, A., Camous, S., Bocquier, F., Barillet, F., \& Hassoun, P. (2015). The effects of parity, litter size, physiological state, and milking frequency on the metabolic profile of Lacaune dairy ewes. Domestic Animal Endocrinology, 50(1), 32-44. doi:10.1016/j. domaniend.2014.07.001

Hermuche, P., Guimarães, R. F., Carvalho, O. A., Jr., Gomes, R. A. T., Paiva, S. R., \& McManus, C. M. (2013). Environmental factors that affect sheep production in Brazil. Applied Geography, 44(1), 172-181. doi: 10.1016/j. apgeog.2013.07.016

Instituto Adolfo Lutz (1985). Normas analíticas do Instituto Adolfo Lutz. Métodos químicos e físicos para análise de alimentos (3nd ed.). São Paulo, SP: Author.

Kearl, L. C. (1982). Nutrients requeriments of ruminants in developing countries. Logan: UT. International Feedstuffs Institute.

Kenyon, P. R., Maloney, S. K., \& Blache, D. (2014). Review of sheep body condition score in relation to production characteristics. New Zealand Journal of Agricultural Research, 57(1), 38-64. doi: 10.1080/0 0288233.2013 .857698

Knapik, J., Ropka-Molik, K., \& Pieszka, M. (2017). Genetic and nutritional factors determining the production and quality of sheep meat a review. Annals of Animal Science, 17(1), 23-40. doi: 10.1515/ aoas-2016-00 36

Lotfollahzadeh, S., Zakian, A., Tehrani-Sharif, M., \& Watson, D. G. (2016). Assessment the alterations of some biochemical parameters in Afshari sheep with possible metabolic disorders. Small Ruminant Research, 145, 58-64. doi: 10.1016/j. smallrumres.2016.10.012 
Mangilli, L. G. (2016). Parâmetros sanitários e produtivos de ovelhas e cordeiros suplementados com aditivo a base de extrato de própolis. Dissertação de mestrado, Universidade Estadual de Londrina, Londrina, PR, Brasil.

Moreira, R. T., Assis, L. C., Lima, E. M. M., Facury, E. J., Fo., \& Borges, J. R. J. (2019). Perfil metabólico durante o periparto de ovelhas da raça Santa Inês com gestação simples e múltipla. Ciência Animal Brasileira, 20, 1-15. doi: 10.1590/1089-6891v20e-34181

Nascimento, P. M., Morgado, A. A., Nunes, G. R., Nikolaus, J. P., Weigel, R. A., Lima, A. S.,... Sucupira, M. C. A. (2015). Metabolismo oxidativo e perfil bioquímico de ovelhas Santa Inês no período periparto: efeito da suplementação parenteral com vitamina E. Semina: Ciências Agrárias, 36(3), 13971408. doi: 10.5433/1679-0359.2015v36n 3p1397

Nasciutti, N. R., Tsuruta, S. A., Oliveira, R. S. B. R., Bisinoto, M., Headley, S. A., Mundim, A. V.,... Saut, J. P. E. (2012). Perfil metabólico em ovelhas Santa Inês, com baixo escore de condição corporal, no periparto. Boletim de Indústria Animal, 69(2), 137-145.

Nitsche, P. R., Caramori, P. H., Ricce, W. S., \& Pinto, L. F. D. (2019). Atlas climático do estado do Paraná. Londrina, PR: Instituto Agronômico do Paraná. Recuperado de http://www.iapar.br/pagina-677.html

Ortunho, V. V., Marçal, W. S., Carvalho, G. S. P., Carli, M. E. S., \& Beline, M. (2016). Correlation between blood variables of the protein profile and $\beta$-hydroxybutyrate in ewe lambs. Brazilian Journal of Hygiene and Animal Sanity, 10(2), 243-251. doi: 10.5935/1981-2965.20160021
Podleskis, M. R., Ribeiro, E. L. A., Rocha, M. A., Silva, L. D. F., Mizubuti, I. Y., Mori, R. M.,... Casimiro, T. R. (2005). Produção de leite de ovelhas Hampshire Down e lle de France até os 84 dias de lactação. Semina: Ciências Agrárias, 26(1), 117-123. doi: 10.5433/1679-0359.2005v26n1p117

Raoofi, A., Jafarian, M., Safi, S., \& Vatankhah, M. (2013). Fluctuations in energy-related metabolites during the peri-parturition period in Lori-Bakhtiari ewes. Small Ruminant Research, 109(1), 64-68. doi: 10.10 16/j.smallrumres.2012.06.012

Ribeiro, E. L. A., \& González-García, E. (2016). Indigenous sheep breeds in Brazil: potential role for contributing to the sustainability of production systems. Tropical Animal Health and Production, 48(7), 1305-1313. doi: 10.1007/s11250016-1109-3

Ribeiro, E. L. A., Mizubuti, I. Y., Rocha, M. A., Silva, L. D. F., Bergamo, H., Mori, R. M.,... Ferreira, D. O. L. (2004). Uso da ocitocina na estimativa de produção e composição do leite de ovelhas Hampshire Down. Revista Brasileira de Zootecnia, 33(6), 1833-1838. doi: 10.1590/S1516-3598200 4000700022

Russel, A. J. F. (1984). Means of assessing the adequacy of nutrition of pregnant ewes. Livestock Production Science, 11(4), 429436. doi: 10.1016/0301-6226(84)90054-X

Santos, F. C. O., Mendonça, C. L., Silva, A. P., Fo., Carvalho, C. C. D., Soares, P. C., \& Afonso, J. A. B. (2011). Indicadores bioquímicos e hormonais de casos naturais toxemia da prenhez em ovelhas. Pesquisa Veterinária Brasileira, 31(11), 974-980. doi: 10.1590/ s0100-736X2011001100006 
Souto, R. J. C., Afonso, J. A. B., Mendonça, C. L., Dantas, A. F. M., Cajueiro, J. F. P., Gonçalves, D. N. A.,... Soares, P. C. (2019). Biochemical, endocrine, and histopathological profile of liver and kidneys of sheep with pregnancy toxemia. Pesquisa Veterinária Brasileira, 39(10), 780-788. doi: 10.1590/1678-51 50-pvb-6400

Virgilio, A., \& Morales, J. M. (2016). Towards evenly distributed grazing patterns: Including social context in sheep management strategies. PeerJ, 4(e2152). doi: 10.7717/peerj.2152
Yang, C. T., Wang, C. M., Zhao, Y. G., Chen, T. B., Aubry, A., Gordon, A. W., \& Yan, T. (2020). Updating maintenance energy requirement for the current sheep flocks and the associated effect of nutritional and animal factors. Animal, 14(2), 295302. doi: 10.1017/S1751731119002064 
